\title{
Raphidascaris (Ichthyascaris) etelidis n. sp. (Nematoda, Anisakidae), a new ascaridoid nematode from lutjanid fishes off New Caledonia
}

\author{
František MORAVEC \\ Institute of Parasitology, \\ Biology Centre of the Academy of Sciences of the Czech Republic, \\ Branišovská 31, 37005 České Budějovice (Czech Republic) \\ moravec@paru.cas.cz \\ Jean-Lou JUSTINE \\ Muséum national d'Histoire naturelle, \\ UMR 7138 Systématique, Adaptation, Évolution, \\ case postale 51, 57 rue Cuvier, 75231 Paris cedex 05 (France) \\ justine@mnhn.fr
}

KEY WORDS

Parasitic nematode,

Raphidascaris,

Ichthyascaris, Etelis,

Pristipomoides, marine fishes,

New Caledonia,

South Pacific, new species.
Moravec F. \& Justine J.-L. 2012. - Raphidascaris (Ichthyascaris) etelidis n. sp. (Nematoda, Anisakidae), a new ascaridoid nematode from lutjanid fishes off New Caledonia. Zoosystema 34 (1): 113-121. DOI: http://dx.doi.org/10.5252/z2012n1a4

\begin{abstract}
A new nematode species, Raphidascaris (Ichthyascaris) etelidis n. sp. (Anisakidae), is described from male and female specimens found in the intestine of the deep-water longtail red snapper Etelis coruscans Valenciennes, 1862 (type host) and the crimson jobfish Pristipomoides filamentosus (Valenciennes, 1830) (both Lutjanidae, Perciformes) from off the southwestern coast of New Caledonia, South Pacific. Based on light and scanning electron microscopy examination, the new species differs from other eight representatives of the subgenus Ichthyascaris Wu, 1949 mainly in the length of spicules $(345-474 \mu \mathrm{m})$, representing $1.5-2.5 \%$ of the body length, and in the presence of small cuticular spines on the tail tip of both sexes and 60-65 pairs of male genital papillae of which 12-13 are postanal. This is the first species of this subgenus reported from fishes of the family Lutjanidae and the second nominal species of Raphidascaris (Ichthyascaris) recorded from New Caledonian waters. Unidentifiable juveniles and rarely adults of Raphidascaris (Ichthyascaris) sp. were collected from Lutjanus vitta (Quoy \& Gaimard, 1824) (Lutjanidae) and Lethrinus genivittatus Valenciennes, 1830, L. miniatus (Forster, 1801) and L. rubrioperculatus Sato, 1978 (all Lethrinidae).
\end{abstract}

\section{RÉSUMÉ}

Raphidascaris (Ichthyascaris) etelidis n. sp. (Nematoda, Anisakidae), nouveau nématode ascaridoïde de poissons Lutjanidae de Nouvelle-Calédonie.

Une nouvelle espèce de nématode, Raphidascaris (Ichthyascaris) etelidis n. sp. (Anisakidae), est décrite de spécimens mâles et femelles trouvés dans l'intestin 
MOTS CLÉS

Nématode parasite,

Raphidascaris,

Ichthyascaris, Etelis,

Pristipomoides, poissons marins,

Nouvelle-Calédonie,

Pacifique sud, espèce nouvelle. du vivaneau flamme Etelis coruscans Valenciennes, 1862 (hôte-type) et du vivaneau blanc Pristipomoides filamentosus (Valenciennes, 1830) (tous deux Lutjanidae, Perciformes) pêchés en eau profonde au large de la côte sud-ouest de la Nouvelle-Calédonie, Pacifique sud. Sur la base d'observations en microscopie photonique et électronique à balayage, la nouvelle espèce diffère des huit autres membres du sous-genre Ichthyascaris Wu, 1949 principalement par la longueur des spicules (345-474 $\mu \mathrm{m})$, représentant 1,5-2,5\% de la longueur du corps, la présence de petites épines cuticulaires sur l'extrémité de la queue des deux sexes et 60-65 paires de papilles génitales mâles dont 12-13 sont postanales. C'est la première espèce du sous-genre mentionnée chez des poissons Lutjanidae et la seconde espèce nominale de Raphidascaris (Ichthyascaris) signalée des eaux de la Nouvelle-Calédonie. Des juvéniles non identifiables et de rares adultes de Raphidascaris (Ichthyascaris) sp. ont été récoltés chez le Lutjanidae Lutjanus vitta (Quoy \& Gaimard, 1824) et les Lethrinidae Lethrinus genivittatus Valenciennes, 1830, L. miniatus (Forster, 1801) et L. rubrioperculatus Sato, 1978.

\section{INTRODUCTION}

Parasitological examinations of deep-sea marine fishes from the external slope of the barrier reef of New Caledonia yielded, among other helminths (Bray \& Justine 2009; Moravec \& Justine 2010, 2011), adult ascaridoid nematodes referable to the subgenus Ichthyascaris Wu, 1949 of the genus Raphidascaris Railliet \& Henry, 1915 parasitizing the intestine of two species of lutjanid fishes: deep-water longtail red snapper Etelis coruscans Valenciennes, 1862 and crimson jobfish Pristipomoides filamentosus (Valenciennes, 1830) (both Lutjanidae, Perciformes). Results of their taxonomic evaluation, based on detailed light microscopy (LM) and scanning electron microscopy (SEM) examinations, have indicated that they represent a new species, which is described below. No specimen was found in three Etelis carbunculus Cuvier, 1828 examined.

Nematodes of Raphidascaris (Ichthyascaris) are known as intestinal parasites of marine fishes. The only species of this subgenus previously known to occur in New Caledonian waters is $R$. (I.) nemipteri Moravec \& Justine, 2005, a parasite of the forked-tailed threadfin bream Nemipterus furcosus (Valenciennes, 1830) (Nemipteridae, Perciformes) (see Moravec \& Justine 2005). Unidentifiable juveniles and rarely also adults of Raphidascaris
(Ichthyascaris) were also collected from Lutjanus vitta (Quoy \& Gaimard, 1824) (Lutjanidae) and Lethrinus genivittatus Valenciennes, 1830, L. miniatus (Forster, 1801) and L. rubrioperculatus Sato, 1978 (all Lethrinidae). This paper adds new species to the list of helminths recently reported from deepsea fishes off New Caledonia (Beveridge \& Justine 2006, 2007; Moravec \& Justine 2007, 2010, 2011 ; Justine 2008, 2009a, b, 2011; Bray \& Justine 2009, 2010; Justine \& Henry 2010).

Etelis coruscans (maximum body length $120 \mathrm{~cm}$ ) and Pristipomoides filamentosus (maximum body size $100 \mathrm{~cm}$ ) are tropical, deep-water, highly commercial fishes and gamefishes distributed in the Indo-Pacific, from eastern Africa to the Hawaiian Islands and Tahiti, north to southern Japan, south to Australia and Lord Howe Island; both are native to New Caledonia (Froese \& Pauly 2011).

\section{MATERIAL AND METHODS}

Fish were caught with long lines at depths of 150$300 \mathrm{~m}$ along the external slope of the barrier reef, off Noumea, New Caledonia. All fish were measured, weighed and photographed, and assigned a unique registration number (JNC). The nematodes for morphological studies were fixed in hot $4 \%$ formaldehyde 
solution, sometimes in hot water then $70 \%$ ethanol. For light microscopical examination (LM), they were cleared with glycerine. Drawings were made with the aid of a Zeiss microscope drawing attachment. Specimens used for scanning electron microscopy (SEM) were postfixed in 1\% osmium tetroxide, dehydrated through a graded acetone series, critical point dried and sputter-coated with gold; they were examined using a JEOL JSM-7401F scanning electron microscope at an accelerating voltage of $4 \mathrm{kV}$ (GB low mode). All measurements are in micrometres unless otherwise stated. Fish names follow FishBase (Froese \& Pauly 2011).

Type and voucher specimens of $R$. (I.) etelidis $\mathrm{n}$. sp. have been deposited in the Muséum national d'Histoire naturelle, Paris, and in the Institute of Parasitology, Biology Centre of the Academy of Sciences of the Czech Republic in České Budějovice (see below). Materials of specifically unidentified Raphidascaris (Ichthyascaris) sp. from the host digestive tract and/ or abdominal cavity (mostly free or encapsulated larvae, quite rarely also poorly preserved adults) from Lutjanus vitta, Lethrinus genivittatus, L. miniatus and L. rubrioperculatus have been deposited in the Muséum national d'Histoire naturelle, Paris (MNHN JNC1924, JNC1951, JNC2038, JNC2158, JNC2184, JNC2207, JNC2208, JNC2227, JNC2266, JNC2306, JNC2312, JNC2314, JNC2315, JNC2327, JNC2455).

\section{SYSTEMATICS}

Family ANISAKIDAE Railliet \& Henry, 1912

Raphidascaris (Ichthyascaris) etelidis n. sp. (Figs 1-3)

DePOSITION OF SPECIMENS. - Muséum national d'Histoire naturelle, Paris (MNHN JNC2616, JNC2617, JNC2623, holotype, allotype and 30 paratypes; JNC2459 and JNC2460, voucher specimens). - Institute of Parasitology, Biology Centre of the Academy of Sciences of the Czech Republic, České Budějovice (N-969, 4 paratypes).

Type LOcality. - Off New Caledonia, South Pacific Ocean.

ETYMOLOGY. - The specific name of this nematode relates to the genitive form of the generic name of the host.
TYPE HOST. - Deep-water longtail red snapper, Etelis coruscans Valenciennes, 1862 (Lutjanidae, Perciformes).

Other host. - Crimson jobfish, Pristipomoides filamentosus (Valenciennes, 1830) (Lutjanidae).

Site OF InfeCtion. - Intestine.

PreValenCe AND InTENSITY. - Etelis coruscans: 3 fish infected/5 fish examined; 2-38 (mean 9) specimens per fish. Pristipomoides filamentosus: 2/2; 1-10 (mean 5).

\section{DESCRIPTION}

Medium-sized, whitish nematodes with transversely striated cuticle. Lips nearly equal in size (dorsal lip slightly smaller than ventrolateral lips), broader than long, without lateral membranous flanges; pulp with two distinct anterior lobes, each internally with terminal pocket-like depression. Dorsal lip bears two subdorsal double papillae at approximately anterior $1 / 3$ of its length; each ventrolateral lip with one double subventral papilla, one small single papilla and amphid situated laterally (Figs 1B, F; 2A, C). Interlabia absent. Narrow lateral alae extend along whole body length, united anteriorly close to ventrolateral lips on one side of body (Figs 1A; 2B, C) and form cordons on tail (Fig. 2D, E). Oesophagus short; posterior half markedly broad (Fig. 1A). Ventriculus transversely oval; ventricular appendix relatively short. Excretory pore posterior to level of nerve ring. Tail of both sexes conical.

Male

Seven specimens; measurements of holotype in parentheses.

Length of body 13.87-27.65 (19.19) mm, maximum width 435-830 (666). Lips 82-136 (109) long. Length of oesophagus 1.34-2.30 (2.30) (7.8-12 [12]\% of body length), maximum width 204-340. Nerve ring and excretory pore 381-625 (476) and 482-775 (775), respectively, from anterior extremity. Ventriculus 109-163 × 163-286 $(109 \times 218)$; ventricular appendix 585-925 (585) long, 122-177 (122) in maximum width. Posterior end of body curved ventrally. Spicules equal, alate, pointed, 345-474 (474) long, representing 1.5-2.5 (2.5)\% of body length. Total of 60-65 (62) pairs of small subventral papillae present, 44-49 (49) being preanals and 12-13 (13) postanals; papillae of several 
posteriormost preanal pairs and of postanal pairs very small; postanal papillae of third pair from posterior extremity doubled (Fig. 2F). Anterior cloacal lip with poorly developed unpaired median papilla. Tail 109-163 (122) long, ending in small appendage provided with many cuticular spines or protuberances (Figs 1E, I; 3D, E). Ventral and subventral surface of body in region of genital papillae bearing distinctly modified cuticle (Figs 2F; 3E, F).

\section{Female}

Seven gravid specimens; measurements of allotype in parentheses.

Length of body 24.13-26.89 (26.63) mm, maximum width 775-938 (775). Lips 122-150 (122) long. Length of oesophagus 2.15-2.42 (2.30), representing 8.1-9.4 (8.1)\% of body length, maximum width 299-476 (299). Nerve ring and excretory pore 503-639 (503) and 745-979 (979), respectively, from anterior extremity. Ventriculus 136-163 $\times$ 272-313 (150 × 313); ventricular appendix 6121047 (1047) long, maximum width 109-177 (109). Vulva situated in anterior region of body, 3.334.69 (4.30) $\mathrm{mm}$ from anterior extremity, at 14-18 (16)\% of body length; vagina directed posteriorly from vulva. Uterus forms coils in region posterior to vagina, extending posteriorly to level of rectum. Eggs numerous, suboval to almost rounded, thinwalled, smooth, with uncleaved contents (Fig. 1D); size 54-57 × 45-54 (54 × 48). Tail 544-639 (639) long; tip with numerous minute cuticular spines (Figs 1E; 2D).

\section{DISCUSSION}

Wu (1949) established a new genus Ichthyascaris to accommodate his newly described species $I$. lophii Wu, 1949. However, subsequent authors (Hartwich 1957; Chabaud 1965; Smith 1984; Moravec 1994) considered Ichthyascaris a synonym of Raphidascaris Railliet \& Henry, 1915. Bruce (1990) and Bruce et al. (1994) re-established Ichthyascaris as an independent genus mainly on the basis of simple lips without lateral membranous flanges and the presence of lateral alae which unite close to the ventrolateral lips. However, Moravec \& Nagasawa
(2002) redescribed the Japanese species Raphidascaris gigi Fujita, 1928, transferred to Ichthyascaris by Bruce (1990), and found that, while the lips were typical of Ichthyascaris, the lateral alae were lacking. The same concerns Raphidascaris lutjani Olsen, 1952 and $R$. mediterraneus Lèbre \& Petter, 1983, both transferred by Bruce (1990) to Ichthyascaris (see Lèbre \& Petter 1983; Smith 1984). Therefore, Moravec \& Nagasawa (2002) considered Ichthyascaris, characterized principally by the presence of lateral alae united anteriorly, as a subgenus of Raphidascaris.

At present, the following eight species can be considered to belong to the subgenus Raphidascaris (Ichthyascaris): R. chirocentri Yamaguti, 1935, R. fisheri (Hooper, 1983), R. gymnocraniae (Bruce, 1990), $R$. lophii (Wu, 1949), R. nemipteri Moravec \& Justine, 2005, R. sillagoides (Bruce, 1990), R. trichiuri (Yin \& Zhang, 1983) and R. vicentei Santos, 1970.

The new species, $R$. etelidis n. sp., differs distinctly from $R$. fisheri and $R$. trichiuri in the presence of numerous small cuticular spines on the tail tip; from the former species also by the absence of a small bulge posterior to the anterolateral sockets on the lateral margins of the lips (see Bruce 1990; Luo \& Huang 2001). Although the male and female body lengths of $R$. lophii are much the same as those in the new species, the spicules are distinctly longer (540-690 vs 345-474), representing about 3 (vs $1.5-2.5) \%$ of the body length; the original description of $R$. lophii by Wu (1949), based on specimens from Lophius litulon (Jordan, 1902) (Lophiidae) in China (Shanghai), is very incomplete and Smith (1984) designated this species a species inquirenda.

In the body length and the number of male genital papillae, the new species resembles $R$. chirocentri, but distinctly differs in having longer spicules (345-474 vs 315), representing 1.5-2.5 (vs 3.3)\% of body length, and the vulva is usually situated more anteriorly (at $14-18$ vs $17-25 \%$ of body length) (Yamaguti 1935; Mozgovoy 1953). In contrast to $R$. etelidis n. sp., $R$. sillagoides and $R$. vicentei have shorter spicules (282-306 and 125300 vs 345-474), less numerous total numbers of the pairs of genital papillae (31-37 and 41-51 vs 60-65) and of postanal papillae (8-10 and 1011 vs $12-13)$, and the latter species has a smooth 
A

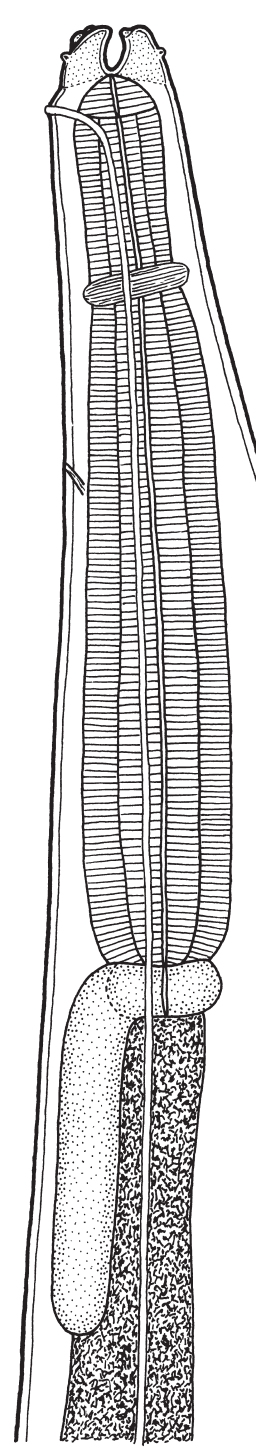

B

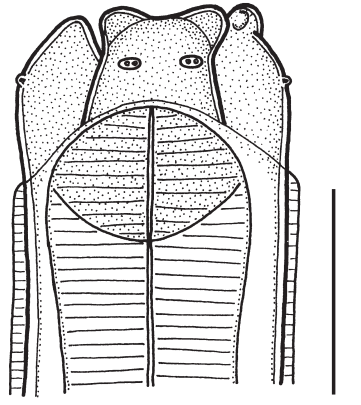

C

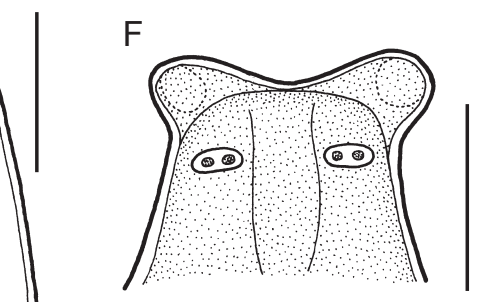

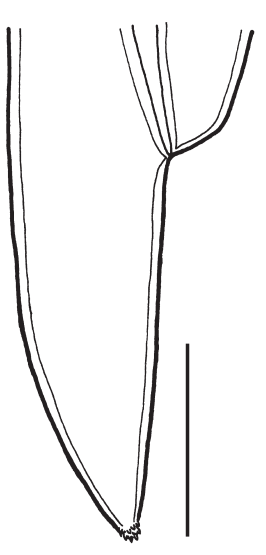

D

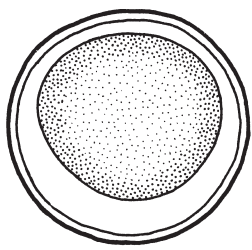

E

$\mathrm{D}, \mathrm{E}$

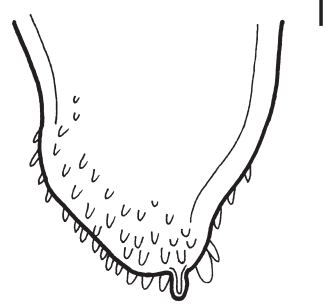

G

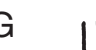

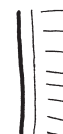
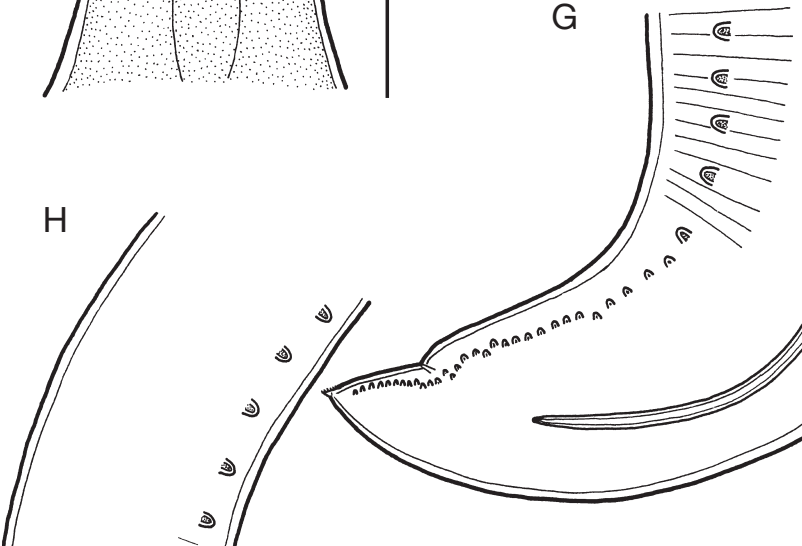

())
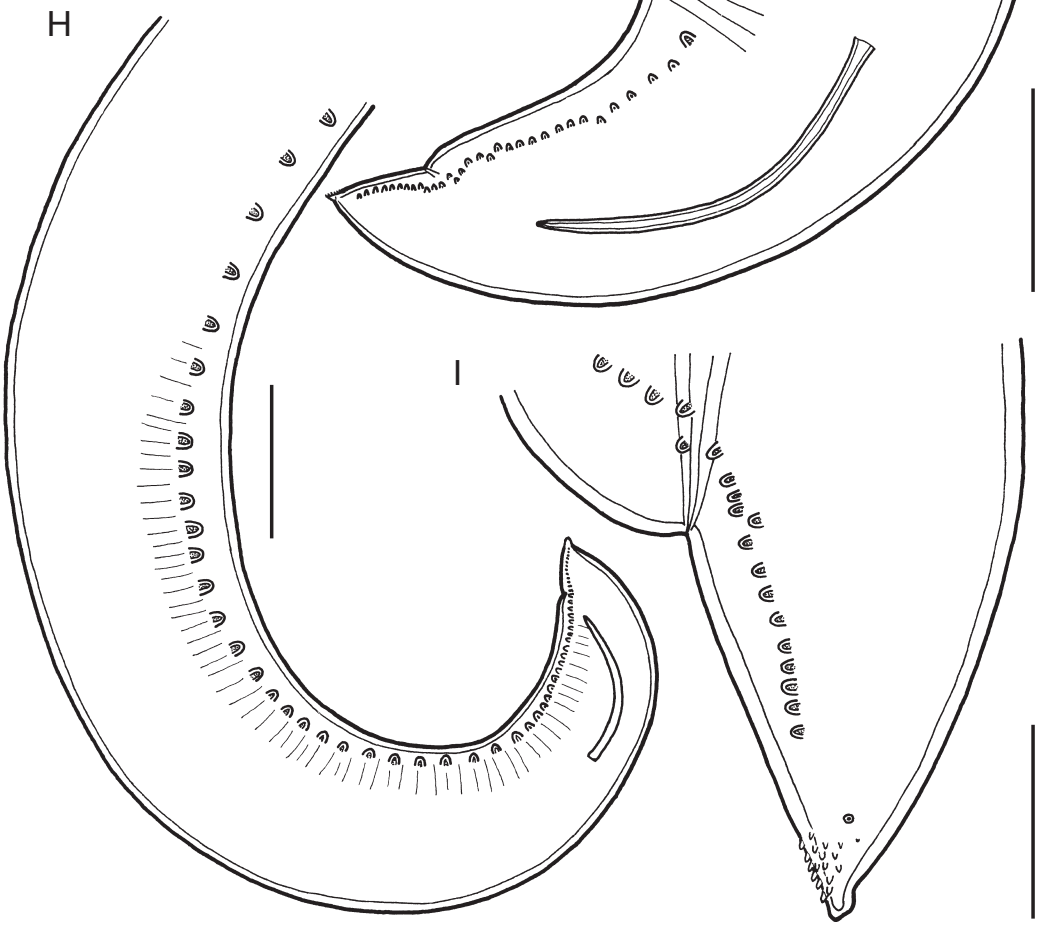

*
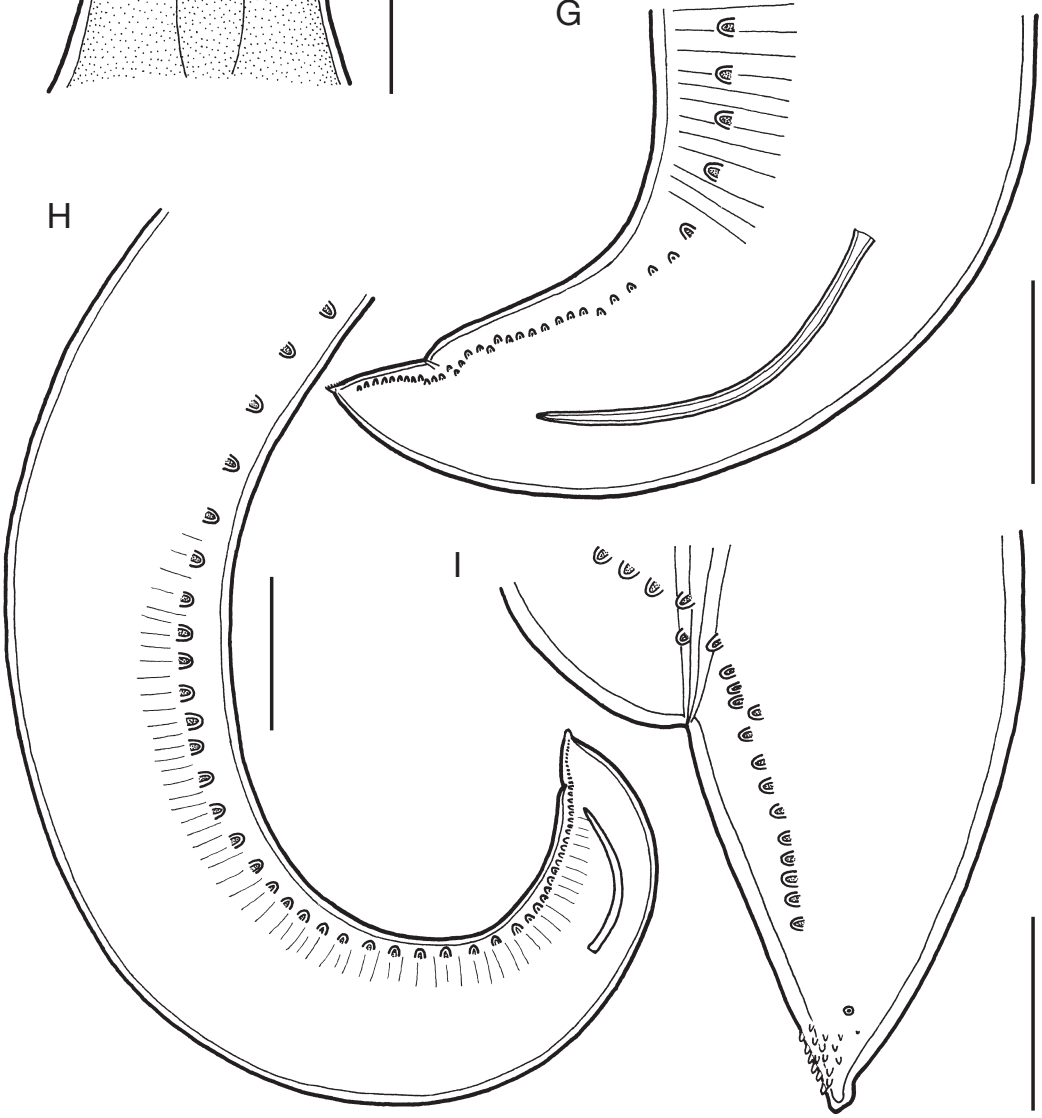

FIG. 1. - Raphidascaris (Ichthyascaris) etelidis n. sp. from Etelis coruscans Valenciennes, 1862; A, anterior end of male, lateral view; B, anterior end of female, dorsal view; C, tail of gravid female, lateral view; D, egg; E, tip of female tail, lateral view; F, dorsal lip; $\mathbf{G}$, posterior end of male, lateral view; $\mathbf{H}$, posterior end of male (smaller magnification) showing all pairs of caudal papillae, lateral view; I, tail of male, lateral view. Scale bars: A, H, $300 \mu \mathrm{m} ; \mathrm{B}, \mathrm{C}, \mathrm{G}, 200 \mu \mathrm{m} ; \mathrm{D}, \mathrm{E}, 30 \mu \mathrm{m} ; \mathrm{F}, 100 \mu \mathrm{m} ; \mathrm{I}, 50 \mu \mathrm{m}$. 

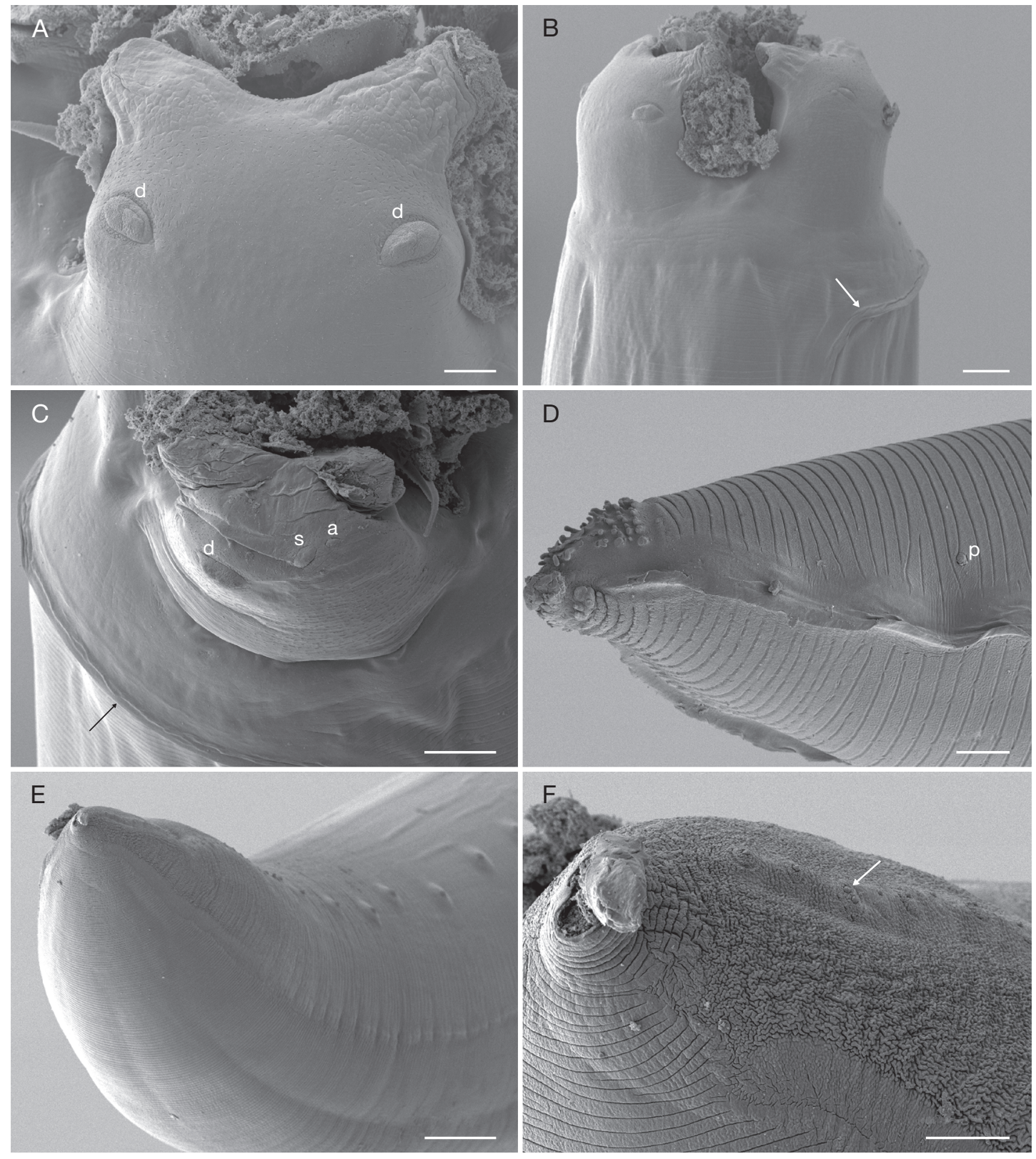

FIG. 2. - Raphidascaris (Ichthyascaris) etelidis n. sp. from Etelis coruscans Valenciennes, 1862, scanning electron micrographs; A, dorsal lip; B, anterior end, lateral view (arrow indicates joining lateral alae); C, region of cephalic end with subventral lip, ventrolateral view (arrow indicates ventral connection of lateral alae); D, posterior part of female tail, lateral view; E, posterior end of male, sublateral view; F, male tail with postanal papillae, lateral view (arrow indicates double papilla). Abbreviations: a, amphid; d, double cephalic papilla; p, phasmid; s, single cephalic papilla. Scale bars: A, D, F, $10 \mu \mathrm{m} ; \mathrm{B}, \mathrm{C}, 20 \mu \mathrm{m} ; \mathrm{E}, 50 \mu \mathrm{m}$. 

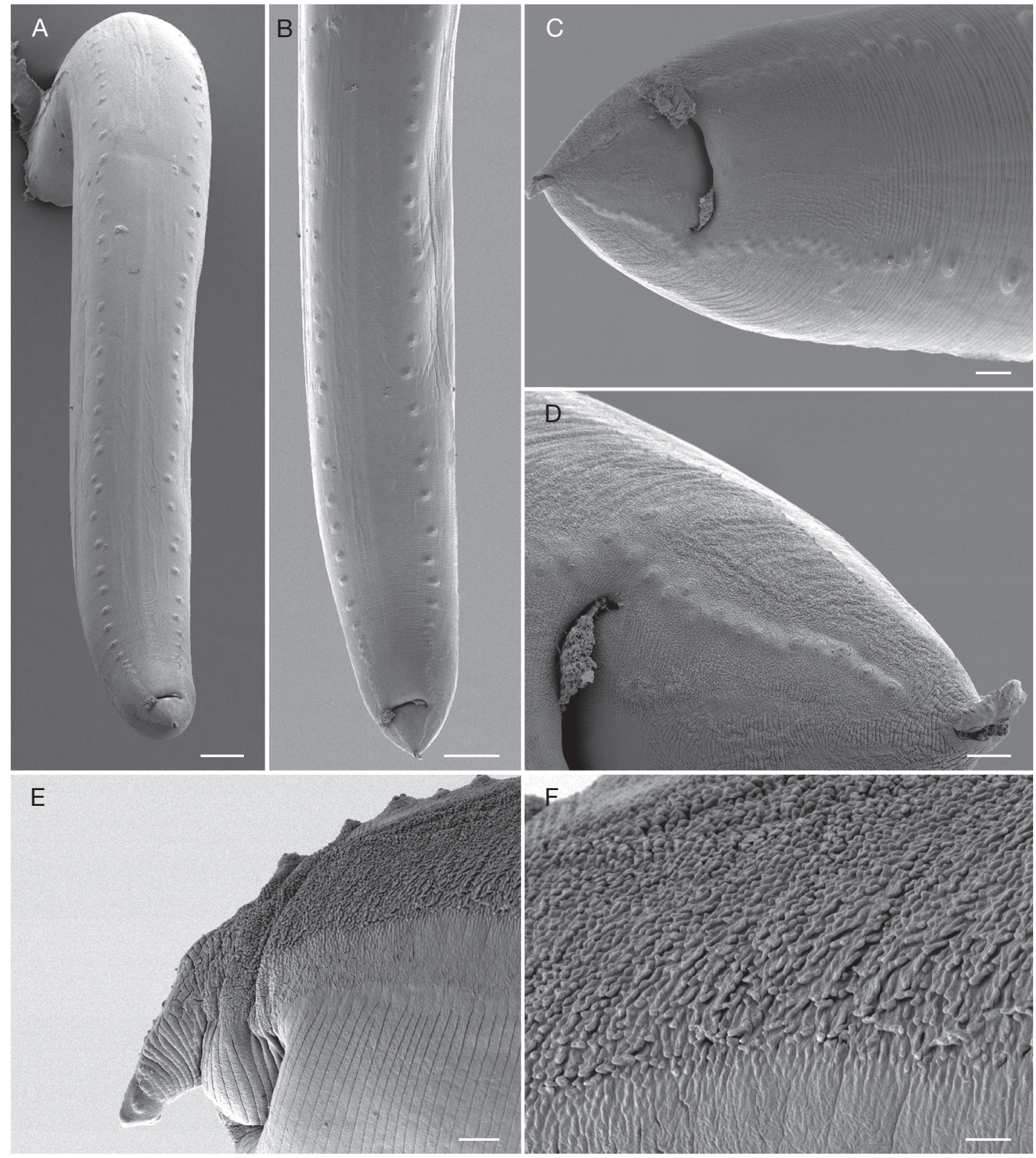

FIG. 3. - Raphidascaris (Ichthyascaris) etelidis n. sp. from Etelis coruscans Valenciennes, 1862, scanning electron micrographs; A, posterior end of male (with complete number of paired preanal papillae), ventral view; B, same (number of paired papillae incomplete), somewhat larger magnification; C, posterior end of male (region of small caudal papillae), ventral view; $\mathbf{D}$, distribution of caudal papillae on male tail, ventral view; $\mathbf{E}$, posterior part of male tail with distinctly modified subventral cuticle, lateral view; $\mathbf{F}$, detail of modified subventral cuticle on male tail, lateral view. Scale bars: A, B, $100 \mu \mathrm{m} ; \mathrm{C}, 20 \mu \mathrm{m} ; \mathrm{D}, 10 \mu \mathrm{m} ; \mathrm{E}, 50 \mu \mathrm{m} ; \mathrm{F}, 2 \mu \mathrm{m}$. 
(aspinose) male tail tip and more elongate lips without markedly protruding inner lobes on their anterior ends (Deardorff \& Overstreet 1981; Smith 1984; Bruce 1990). Raphidascaris gymnocraniae and $R$. nemipteri differ in having a lesser number of pairs of preanal papillae (24-28 and 22-33 vs 44-49) and of postanal papillae (7-8 and 8-11 vs 12-13), and in usually shorter spicules (306-353 and 225-399 vs 345-474); in addition, the papillae of the third pair from the posterior extremity are not doubled in the former species, whereas the latter species has a smooth (aspinose) male tail tip (Bruce 1990; Moravec \& Justine 2005).

Moreover, all the above-mentioned species of Raphidascaris (Ichthyascaris) differ from the new species in the type of host. Raphidascaris etelidis n. sp. is the first species of this subgenus reported from fishes of the family Lutjanidae (see Bruce et al. 1994). Bruce (1990) transferred Raphidascaris lutjani Olsen, 1952, a parasite of Lutjanus analis (Cuvier, 1828) (Lutjanidae) in Florida, USA, to Ichthyascaris in his conception, but, based on data of Smith (1984), in this paper it is retained in the nominotypical subgenus Raphidascaris (Raphidascaris). Raphidascaris lutjani conspicuously differs from $R$. etelidis n. sp. in having lateral alae with straight anterior ends and unusually long (1.06-1.09 $\mathrm{mm}$ ) spicules (Olsen 1952; Smith 1984). Many species of Raphidascaris (Ichthyascaris) also differ from R. etelidis n. sp. in the geographical distribution: only four of them, $R$. fisheri, R. gymnocraniae, R. nemipteri and R. sillagoides, have been reported from the South Pacific Ocean in the Australian region. Raphidascaris etelidis $\mathrm{n}$. sp. is the second species of this subgenus recorded from New Caledonian waters.

In addition to $R$. etelidis n. sp. in Etelis coruscans and Pristipomoides filamentosus, juveniles and rarely adults of Raphidascaris (Ichthyascaris) were collected from Lutjanus vitta (Lutjanidae) and Lethrinus genivittatus, L. miniatus and L. rubrioperculatus (all Lethrinidae) (see also Justine et al. 2010, who included them among unidentifiable larval anisakids). Considering that Lutjanus vitta belongs to the same fish family as the hosts of $R$. etelidis n. sp., it may well be that they are conspecific with this species. However, the only two available males are not well preserved, so that the specific identification of these nematodes is impossible. Moreover, taking into account that in contrast to Lutjanus spp., the hosts of $R$. etelidis $\mathrm{n}$. sp. are deep-sea fishes, the specimens from L. vitta are designated as Raphidascaris (Ichthyascaris) sp. until newly collected materials from this host are at disposal.

\section{Acknowledgements}

Students, Cyndie Dupoux, Sophie Olivier and Pierpaolo Brena, participated in the fishing operations and the parasitological survey. Jean-Raymond Olivier kindly provided fish. Thanks are also due to the staff of the Laboratory of Electron Microscopy of the Institute of Parasitology, Biology Centre of the Academy of Sciences of Czech Republic, in České Budějovice for their technical assistance, and Blanka Škoríková from the Department of Helminthology of the same institute for her help with the preparation of illustrations. This study was partly supported by the research projects of the Institute of Parasitology, Biology Centre of the Academy of Sciences of Czech Republic (Z60220518 and LC522).

\section{REFERENCES}

BEVERIDGE I. \& JustinE J.-L. 2006. — Gilquiniid cestodes (Trypanorhyncha) from elasmobranch fishes off New Caledonia with descriptions of two new genera and a new species. Systematic Parasitology 65: 235-249.

Beveridge I. \& Justine J.-L. 2007. — Paragrillotia apecteta n. sp. and redescription of P. spratti (Campbell \& Beveridge, 1993) n. comb. (Cestoda, Trypanorhyncha) from hexanchid and carcharhinid sharks off New Caledonia. Zoosystema 29: 381-391.

Bray R. A. \& Justine J.-L. 2009. - Neolebouria blatta n. sp. (Digenea: Opecoelidae) from Pristipomoides argyrogrammicus (Valenciennes) and Etelis carbunculus Cuvier (Perciformes: Lutjanidae) off New Caledonia. Systematic Parasitology 74: 161-167.

Bray R. A. \& Justine J.-L. 2010. - Pseudopecoelus sosoae sp. nov. and $P$. sewelli (Digenea, Opecoelidae) from the rare deep-sea fish Neoscombrops pacificus (Perciformes, Acropomatidae) off New Caledonia. Acta Parasitologica 55: 45-52.

BRUCE N. L. 1990. - Hysterothylacium Ward and Magath, 1917, and Ichthyascaris Wu, 1949, ascaridoid nematodes from Australian demersal fishes. Memoirs of the Queensland Museum 28: 389-426. 
BRUCE N. L., AdLARD R. D. \& CANNON L. R. G. 1994.Synoptic checklist of ascaridoid parasites (Nematoda) from fish hosts. Invertebrate Taxonomy 8: 583-674.

Chabaud A. G. 1965. — Ordre des Ascaridida, in Grassé P.-P. (ed.), Traité de Zoologie, tome IV, fascicule 3. Masson et Cie, Paris: 932-1025.

DEARDORFF T. L. \& OverSTREeT R. M. 1981. - Raphidascaris camura sp. n., Hysterothylacium uerycheilum (Olsen) comb. n., and comments on Heterotyphlum Spaul (Nematoda: Ascaridoidea). Journal of Parasitology 67: 426-432.

Froese R. \& Pauly D. (eds) 2011. — FishBase. World Wide Web electronic publication, www.fishbase.org, version $05 / 2011$.

HaRTWICH G. 1957. — Zur Systematik der Nematoden - Superfamilie Ascaridoidea. Zoologische Jahrbücher, Jena (Systematik, Ökologie und Geographie) 85: 211-252.

Justine J.-L. 2008. - Two new species of Pseudorhabdosynochus Yamaguti, 1958 (Monogenea: Diplectanidae) from the deep-sea grouper Epinephelus morrhua (Val.) (Perciformes: Serranidae) off New Caledonia. Systematic Parasitology 71: 145-158.

Justine J.-L. 2009a. - A new species of Triloculotrema Kearn, 1993 (Monogenea: Monocotylidae) from a deep-sea shark, the blacktailed spurdog Squalus melanurus (Squaliformes: Squalidae), off New Caledonia. Systematic Parasitology 74: 59-63.

Justine J.-L. 2009b. - A redescription of Pseudorhabdosynochus epinepheli (Yamaguti, 1938), the type-species of Pseudorhabdosynochus Yamaguti, 1958 (Monogenea: Diplectanidae), and the description of $P$. satyui n. sp. from Epinephelus akaara off Japan. Systematic Parasitology 72: 27-55.

Justine J.-L. 2011. - Protocotyle euzetmaillardi n. sp. (Monogenea, Hexabothriidae) from the bigeye sixgill shark Hexanchus nakamurai Teng (Elasmobranchii, Hexanchidae) off New Caledonia. Systematic Parasito$\log y$ 78: 41-55.

Justine J.-L. \& Henry É. 2010. - Monogeneans from Epinephelus chlorostigma (Val.) (Perciformes: Serranidae) off New Caledonia, with the description of three new species of diplectanids. Systematic Parasitology 77: 81-105.

Justine J.-L., BEVERidge I., Boxshall G. A., Bray R. A., Moravec F. \& Whittington I. D. 2010. - An annotated list of fish parasites (Copepoda, Monogenea, Digenea, Cestoda and Nematoda) collected from emperors and emperor bream (Letherinidae) in New Caledonia further highlights parasite biodiversity estimates on coral reef fish. Zootaxa 2691: 1-40.

Lèbre C. \& Petter A. J. 1983. - Deux nouvelles espèces d'Ascarides (Nematoda) parasites de poissons téléostéens: Raphidascaris mediterraneus n. sp. et Goezia anguillae n. sp.; complément de description de Cucullanus micropapillatus Törnquist, 1931 (Nematoda, Cucullanidae). Bulletin du Muséum national d'Histoire naturelle, 4e série, 5, section A, no. 2: 491-505.

LuO D. \& HuAnG H. 2001. - Heliconema minnanensis n. sp. (Physalopteroidea: Physalopteridae) and Raphidascaris trichiuri (Yin and Zhang) n. comb. (Ascaridoidea: Anisakidae) in marine fishes. Journal of Parasitology 87: 1090-1094.

MoraVEC F. 1994. - Parasitic Nematodes of Freshwater Fishes of Europe. Academia and Kluwer Academic Publishers, Prague and Dordrecht, Boston, London, 473 p.

MoraVEC F. \& NAGASAWA K. 2002. - Redescription of Raphidascaris gigi Fujita, 1928 (Nematoda: Anisakidae), a parasite of freshwater fishes in Japan. Systematic Parasitology 52: 193-198.

Moravec F. \& Justine J.-L. 2005. - Two anisakid nematodes from marine fishes off New Caledonia, including Raphidascaris (Ichthyascaris) nemipteri $\mathrm{n} . \mathrm{sp}$. from Nemipterus furcosus. Systematic Parasitology 62: 101-110.

Moravec F. \& Justine J.-L. 2007. - A new species of Ascarophis (Nematoda, Cystidicolidae) from the stomach of the marine scorpaeniform fish Hoplichthys citrinus from a seamount off the Chesterfield Islands, New Caledonia. Acta Parasitologica 52: 238-246.

Moravec F. \& Justine J.-L. 2010. - Some trichinelloid nematodes from marine fishes off New Caledonia, including description of Pseudocapillaria novaecaledoniensis sp. n. (Capillariidae). Acta Parasitologica 55: 71-80.

Moravec F. \& Justine J.-L. 2011. - Cucullanid nematodes (Nematoda: Cucullanidae) from deep-sea marine fishes off New Caledonia, including Dichelyne etelidis n. sp. Systematic Parasitology 78: 95-108.

Mozgovoy A. A. 1953. - [Ascaridata of Animals and Man and the Diseases Caused by Them.] Osnovy Nematodologii 2. Publishing House of the Academy of Sciences of the USSR, Moscow, 616 p. (In Russian.)

Olsen L. S. 1952. - Some nematodes parasitic in marine fishes. Publications of the Institute of Marine Science, University of Texas 2: 173-215.

SMITH J. D. 1984. - Taxonomy of Raphidascaris spp. (Nematoda, Anisakidae) of fishes, with a redescription of $R$. acus (Bloch, 1772). Canadian Journal of Zoology 62: 685-694.

Wu H. W. 1949. - A note on two parasitic nematodes of fishes. Sinensia 20: 51-57.

YAMAGUTI S. 1935. - Studies on the helminth fauna of Japan. Part 9. Nematodes of fishes, 1. Japanese Journal of Zoology 6: 337-386. 